\title{
SARS-CoV-2: previous coronaviruses, immune response, and development of vaccines
}

\author{
Saraí G. De León-Rodríguez, Brenda Hernández-Rico, Guadalupe Del Olmo-Vázquez, Iván Cruz-Dávalos, \\ and Laura C. Bonifaz*
}

Unidad de Investigación Médica en Inmunoquímica, Hospital de Especialidades Dr. Bernardo Sepúlveda, Centro Médico Nacional Siglo XXI, Instituto Mexicano del Seguro Social, Mexico City, Mexico

\begin{abstract}
Since the emergence of the new severe acute respiratory syndrome coronavirus 2 (SARS-CoV-2) in China at the end of 2019, when its characteristics were practically unknown, one aspect was evident: its high contagion rate. This high infection rate resulted in the spread of the virus in China, Europe, and, eventually, the rest of the world, including Mexico. At present, around 9 million people are infected, and around 470,000 have died worldwide. In this context, the need to generate protective immunity, and especially the generation of a vaccine that can protect the world population against infection in the shortest possible time, is a challenge that is being addressed in different countries using different strategies in multiple clinical trials. This opinion article will present the evidence of the induction of immune response in some of the viruses of the coronavirus family before COVID-19, such as SARS-CoV and MERS-CoV (Middle East respiratory syndrome coronavirus). The information collected about the induction of an immune response by SARS-CoV-2 will be presented, as well as a description of the vaccine candidates reported to date in the various ongoing clinical trials. Finally, an opinion based on the evidence presented will be issued on the potential success of developing vaccine prototypes.
\end{abstract}

Key words: Wuhan coronavirus. SARS-CoV-2 vaccine. COVID-19 vaccine. Ad5-nCoV vaccine. mRNA 1273 vaccine. Bacillus Calmette-Guerin.

\section{SARS-CoV-2: coronavirus previos, respuesta inmune y desarrollo de vacunas}

\section{Resumen}

Desde el surgimiento del nuevo coronavirus SARS-CoV-2 (coronavirus tipo 2 del síndrome respiratorio agudo severo) en China a finales del año 2019, cuando todavía era desconocido prácticamente en todos los aspectos, una característica era evidente: el alto índice de contagio entre la población. Esto resultó en la expansión del virus en China, Europa y, finalmente, en el resto del mundo, incluyendo México. Actualmente, alrededor de 9 millones de personas están infectadas, y han muerto cerca de 500,000 en todo el mundo. En este contexto, la necesidad de generar inmunidad protectora y, sobre todo, el desarrollo de una vacuna que pueda proteger a la población mundial contra la infección en el menor tiempo posible, es un reto que se está abordando en distintos países utilizando diversas estrategias en múltiples ensayos clínicos. En este artículo de opinión se presentan las evidencias de la inducción de respuesta inmunitaria con algunos de los virus de la familia

Correspondence:

*Laura C. Bonifaz

E-mail: labonifaz@yahoo.com

Available online: 07-10-2020

Date of reception: $25-06-2020$

Date of acceptance: 26-06-2020

DOI: 10.24875/BMHIM.200001911
Bol Med Hosp Infant Mex. 2020;77(5):252-261

www.bmhim.com

1665-1146/C 2020 Hospital Infantil de México Federico Gómez. Published by Permanyer. This is an open access article under the CC BY-NC-ND license (http://creativecommons.org/licenses/by-nc-nd/4.0/). 
de coronavirus previos al SARS-CoV-2, como el SARS-CoV (coronavirus del síndrome respiratorio agudo severo) y el MERS-CoV (síndrome respiratorio por coronavirus de Oriente Medio). Además, se presenta lo reportado hasta el momento acerca de la inducción de respuesta inmunitaria por el SARS-CoV-2, así como una descripción de los candidatos a vacunas informados hasta el momento en los distintos ensayos clínicos en curso. Finalmente se emite una opinión, basada en las evidencias presentadas, acerca del éxito potencial de los prototipos de vacunas en desarrollo.

Palabras clave: Coronavirus de Wuhan. Vacuna SARS-CoV-2. Vacuna COVID-19. Vacuna Ad5-nCoV. Vacuna mRNA-1273. Bacilo de Calmette-Guérin.

\section{Introduction}

Since the emergence of the new SARS-CoV-2 (severe acute respiratory syndrome type 2 coronavirus) in Wuhan, China, when it was still virtually unknown, one feature was evident: its high rate of infection among the population. This feature resulted in the spread of the virus, initially in China and Europe, and then in the rest of the world. In Mexico, an approximate mortality of $12 \%$ has been reported ${ }^{1}$. On January 30,2020 , the World Health Organization declared SARS-CoV-2 infection a public emergency, and on March 11, 2020, a global pandemic was declared ${ }^{2}$. At the time of writing this manuscript, about 7.5 million people have been infected, and about 500,000 have died ${ }^{3}$.

SARS-CoV-2 generates a clinical picture characterized by fever, dry cough, and fatigue; some patients experience dyspnea, headache, muscle pain, and diarrhea ${ }^{4}$. Moreover, COVID-19 has been reported to be characterized by an inflammatory response that may contribute to airway damage ${ }^{5}$. Severe cases may progress to acute respiratory distress syndrome (ARDS) 8-9 days after the onset of symptoms, which can lead to respiratory failure, multiple organ failure, and death ${ }^{6,7}$.

It has been shown that the SARS-CoV-2 cell receptor is the angiotensin-2 converting enzyme (ACE-2) and that this virus can infect respiratory tract epithelial cells, alveolar cells, endothelial cells, and macrophages in the lungs ${ }^{8-10}$. The virus expresses on its surface the so-called S-protein (spike), which gives it the appearance of having a "crown". This protein binds to ACE-2 and allows viral infection ${ }^{11,12}$.

Data from patients with SARS-CoV-2 indicate that high levels of neutralizing antibodies are produced after infection; however, the type, level, and timing of the immunity that protects against reinfection remain unknown ${ }^{13}$. A person who has been infected with SARS-CoV-2 will generate a sufficient immune response to avoid reinfection; however, there are reports of recovered persons relapsing into the disease. These cases are rare and appear to be related to the presence of viral debris rather than infecting virus ${ }^{14}$.

\section{Previous coronaviruses: SARS-CoV and MERS-CoV}

SARS-CoV-2 is part of the Coronaviridae family, of which seven viruses can infect humans: four affect the upper respiratory tract (229E, NL63, OC43, and HKU1), and the other three can damage the lower respiratory tract (SARS-CoV, MERS-CoV (Middle East coronavirus respiratory syndrome), and SARS-CoV-2) ${ }^{12}$.

The closest relative to SARS-CoV-2 is SARS-CoV, with a genetic similarity of $79 \%{ }^{15}$. SARS-CoV triggered an epidemic in 2002, leaving about 8000 infected people and approximately 800 deaths. Another coronavirus of epidemiological importance that emerged in 2012 was MERS-CoV, which has left approximately 2500 infected people and 858 deaths. The development of animal models was encouraged to study the pathogenesis and replication of SARS-CoV and MERS-CoV viruses. The knowledge generated from the study of these models has led to a better understanding of SARS-CoV-2 $2^{16,17}$.

MERS-CoV has been shown to infect activated T-cells ${ }^{18}$ and induce late production of cytokines after infection of myeloid cells such as dendritic cells and macrophages ${ }^{19-21}$ in vitro, which may contribute to the failure to eliminate the virus and to develop an effective immune response ${ }^{22}$.

In patients with severe or moderate MERS-CoV infection, virus-specific CD8+ T-cells were detected during the acute phase, while antibodies and CD4+ T-cells appeared later ${ }^{23}$. In some patients, the T-cell response and antibody generation were detectable 2-3 weeks after diagnosis ${ }^{23,24}$. In patients with a mild infection, antibody levels tend to be low and transitory compared with severe cases, in which specific antibody levels have been detected for at least 2 years ${ }^{25}$, while the T-cell response has been detected in all surviving cases, 2 years after infection ${ }^{26}$.

Furthermore, SARS-CoV infection can trigger a range of humoral and cellular immune responses. Specific antibodies against SARS-CoV (immunoglobulin (Ig)G and $\operatorname{lgM}$ ) were detectable approximately 2 weeks after 
infection, reaching a peak at 60 days and remain at high levels for up to 180 days $^{27}$. Moreover, high neutralizing antibody titers and cytotoxic T-cell responses specific to SARS-CoV were detected in patients recovered from SARS. These findings suggest that immune responses, both humoral and cellular, are crucial for the elimination of SARS-CoV infection ${ }^{28,29}$. With these results, it has been proposed that both antibody induction and T-cell response are needed to generate an optimal long-term protective response ${ }^{22}$.

Many therapeutic targets for vaccines have been proposed to stop the spread of these coronaviruses. It is important to remark that most have considered the $S$ protein in its complete structure or its subunits (S1 and S2) because it is the main antigenic component that induces an immune response. Furthermore, it is the protein that the virus uses to enter the host cell ${ }^{17,30}$. One strategy in vaccine development has been the use of an inactivated virus, which has shown a significant production of neutralizing antibodies. For example, in animal models, the activation of Th2 cells (producers of interleukin (IL)-4, IL-5, and IL-13) can promote the production of antibodies; however, Th2 response resulted in the development of eosinophilia and hypersensitivity in the presence of other pro-inflammatory cytokines s, $11-33^{\text {. }}$.

Similarly, vaccines developed with viral DNA produced high neutralizing antibody titers. However, in some cases, Th2 response was exacerbated, probably leading to hypersensitivity. Interestingly, this problem was solved when using combinations of inactivated vaccines and DNA, as this directed the immune response toward a Th1 cell profile, which could reduce the exacerbation of the Th2 phenotype. While DNA vaccines for SARS-CoV have not been promising, it is essential to note that better results have been found for MERS-CoV. In murine models and macaques, neutralizing antibodies were demonstrated, as well as the response of CD4+ and CD8+ T-cells that released interferon-gamma (IFN- $\gamma$ ) and tumor necrosis factor-alpha (TNF- $\alpha$ ), providing humoral and cellular immunity 16,17,32,33.

Another strategy for the development of coronavirus vaccines has been the use of viral vectors, as these showed to efficiently induce both innate and $\mathrm{T}$ - and B-cell-mediated immune responses. However, this type of vaccine produces variable results depending on the preparation and route of administration. When comparing intramuscular and intranasal vaccination, the latter induced a higher neutralizing antibody titer, preventing more effectively the replication of the virus ${ }^{34}$. The production of antibodies was significantly lower than that obtained with the attenuated virus; however, the vaccine was protective against the virus. It is essential to mention that there is pre-existing immunity to some viral vectors, such as human adenovirus serotype 5, which may decrease the efficiency of CD8+ T-cell response ${ }^{16,34,35}$.

New alternatives to avoid these complications have been sought, such as chimpanzee adenoviruses, which have entered clinical trials as viral vectors. As an example, a vaccine encoding the MERS-CoV S protein was developed based on a chimpanzee adenoviral vector (ChAdOx1), which induced high levels of neutralizing antibodies and CD8+ T-cell mediated responses in both mouse and human models (Figure 1) ${ }^{35,36}$.

However, only a small number of SARS-CoV or MERS-CoV vaccines made it into Phase I clinical trials, and none of these reached full development, as an abrupt decline in the incidence of these viruses, and the discovery of adverse effects that could exacerbate the disease, cut the funding for vaccine development. Although the opportunity to advance in the development of vaccines against viruses preceding SARSCoV-2 was lost, the study of the immune response in these coronaviruses shows the importance of inducing both long-lasting neutralizing antibodies and cellular mechanisms (CD4+ Th1 and CD8+ cytotoxic T-cells). Furthermore, the need for platforms to generate protective immunity should be highlighted, as it is not possible to predict when another health emergency might arise from these or other genetically related pathogens.

\section{Present health emergency: SARS-CoV-2 and the development of a vaccine}

Regarding the emergence of the new SARS-CoV-2, it has been observed that most patients generate high neutralizing antibody titers 10-14 days after the onset of symptoms; however, some patients had undetectable antibody titers in their blood ${ }^{13}$. In addition, antibody levels decrease by $11.7 \%$ in more than half of the patients after 2 months of recovery ${ }^{37}$, which suggests that they are not long-lasting and are not the only ones that play an important role in the resolution of the disease. Therefore, a vaccine should not focus solely on generating humoral immunity.

Another significant component of the immune system in the resolution of viral infections is the cellular immune response. Although it has not been studied in-depth for SARS-CoV-2, it could be instrumental in inducing protection against the virus. For example, studies of bronchoalveolar lavage fluid from patients with moderate COVID-19 indicate a high proportion of cells with a transcriptional signature corresponding to 


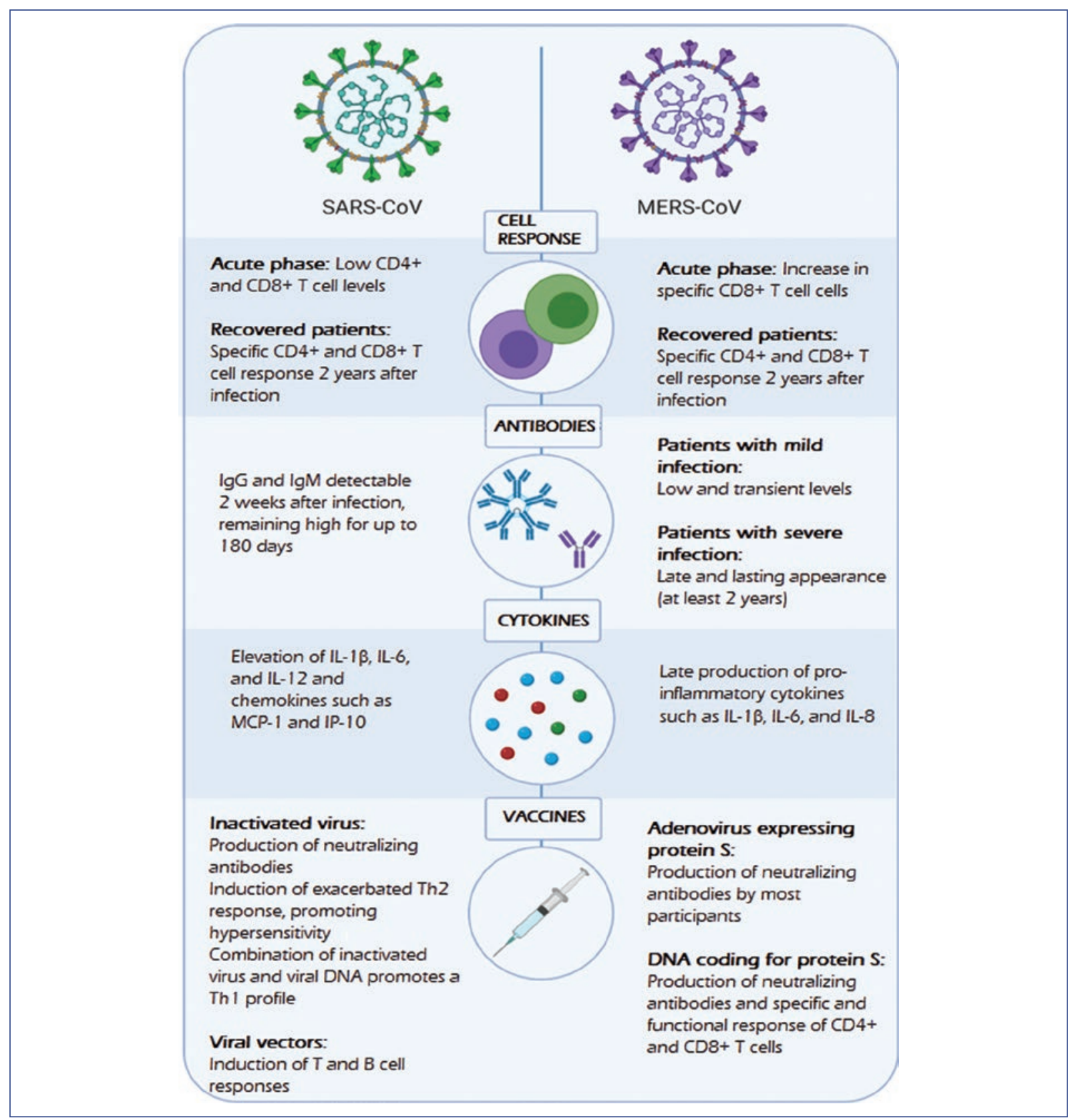

Figure 1. Immune response and vaccines against SARS-CoV and MERS-CoV. SARS-CoV and MERS-CoV are the closest known viruses to SARS-CoV-2; they induce cellular and humoral responses with the production of antibodies and cytokines. Proposed vaccines against these coronaviruses have shown variable results; however, they have served as the basis for the development of SARS-CoV-2 vaccines.

MERS-CoV, Middle East respiratory syndrome coronavirus; SARS-CoV, severe acute respiratory syndrome coronavirus; SARS-CoV-2, severe acute respiratory syndrome type 2 coronavirus.

plasmacytoid and myeloid dendritic cells, as well as the presence of cell infiltrates with a T-cell signature with tissue-resident phenotype, compared to patients who developed a severe condition ${ }^{38}$. Therefore, the presence of these cells is crucial for generating an immune response and achieving a better outcome.
Consequently, the vaccine that succeeds in obtaining these two components will probably achieves the desired succes. In this context, the use of adjuvants or the characterization of viral components capable of activating and inducing this type of response will be of vital importance. 


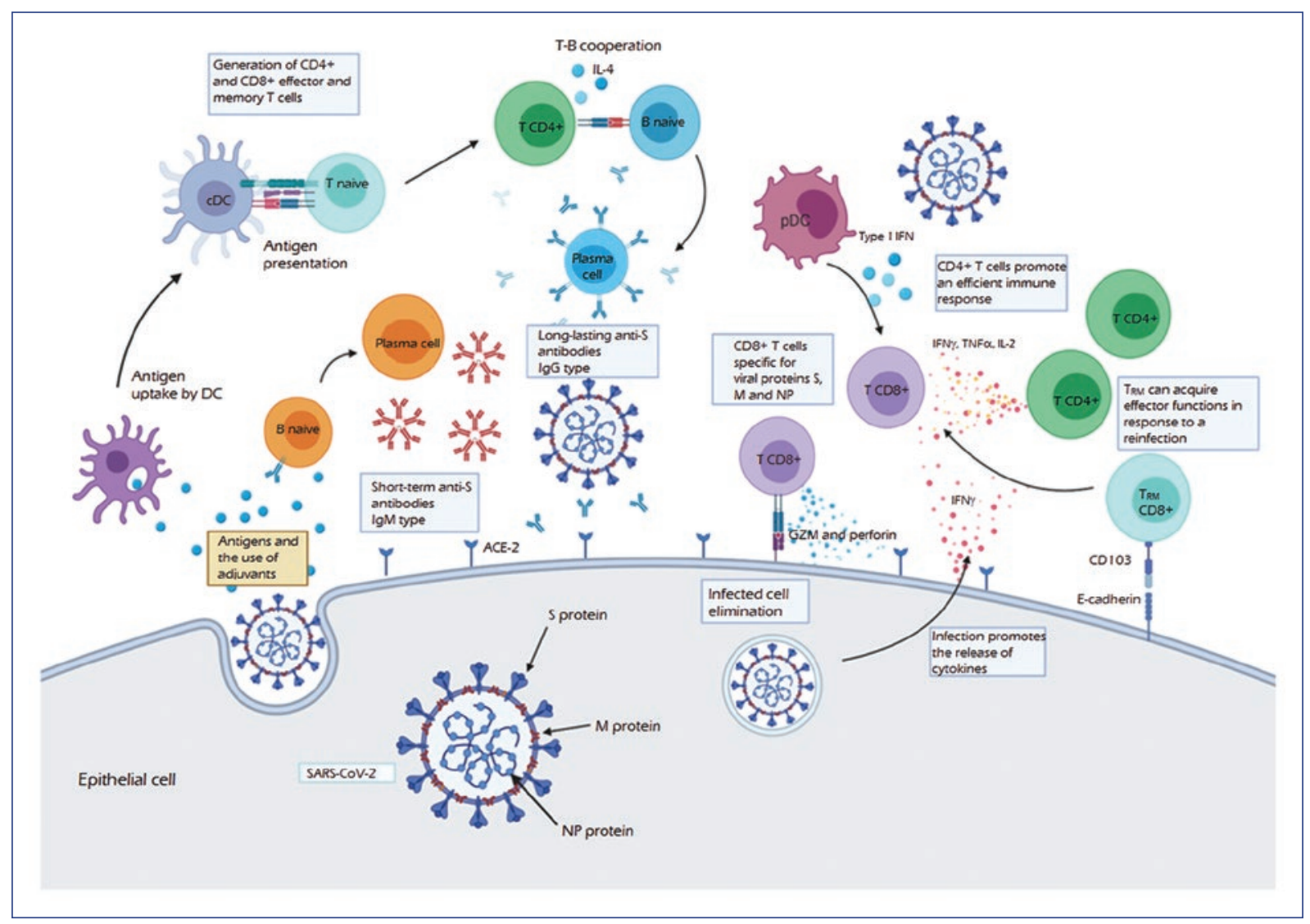

Figure 2. The protective immune response against SARS-CoV-2. Based on preliminary data from studies of COVID-19, the SARS-CoV-2 virus binds to the angiotensin-converting enzyme receptor (ACE-2) through the $S$ (spike) protein, the primary inducer of the immune response. The uptake of this and other antigens such as M (membrane) and NP (nucleocapsid) proteins by dendritic cells (DC), as well as the presence of adjuvants, lead to the antigen presentation, activating CD4+ and TCD8+ effector and memory T-cells. In turn, the infection induces the release of cytokines such as IFN- $\gamma$, promoting the recruitment of T-cell infiltrates. CD4+ T-cells that produce IFN- $\gamma$, TNF- $\alpha$, and IL-2 mount an efficient antiviral immune response, which is enhanced by interferon type I produced by plasmacytoid dendritic cells (pDC). Moreover, CD8+ effector T-cells produce cytotoxic molecules such as granzyme (GZM) and perforin, promoting the death of the infected cell. Furthermore, CD8+ $T_{R M}$ (memory-resident) cells may acquire effector functions for the elimination of infection.

Regarding the humoral response, there is an initial production of $\operatorname{lgM}$, which are short-term antibodies generated by activated plasma cells, usually through an independent T-cell mechanism. Furthermore, activation of a B-cell by a T-cell dependent mechanism is necessary to produce long-lasting antibodies. In this mechanism, TCR-MHC-II interaction and the release of cytokines (such as IL-4) promote the differentiation to plasma cells and the change of the IgM antibody isotype to IgG. The production of neutralizing antibodies specific for the S-protein inhibits the entry of the virus by preventing interaction with its receptor, which would provide protection. These mechanisms - from activation of the humoral to the cellular immune response - would lead to the elimination of and protection against SARS-CoV-2 infection. COVID-19, coronavirus disease 2019; IFN- $\gamma$, interferon-gamma; Ig, immunoglobulin; IL, interleukin; MHC, major histocompatibility complex; SARS-CoV-2, severe acute respiratory syndrome coronavirus 2; TCR, T-cell receptor; TNF- $\alpha$, tumor necrosis factor-alpha.

Furthermore, in ex vivo experiments with COVID-19 convalescent patients, viral $\mathrm{S}, \mathrm{M}$ (membrane), and $\mathrm{N}$ (nucleocapsid) proteins activate CD4+ and CD8+ T-cells. These findings indicate a relationship between the type of clinical picture patients develop and the proportion of CD8+/CD4+ cells specific to viral proteins. When a moderate form develops, the proportion of CD8+ T-cells that produce IL-2, IFN- $\gamma$, and TNF- $\alpha$ is higher than that observed in the severe form, with M and NP proteins promoting a more significant response of these cells. In addition to the $S$ protein, M and NP proteins should be evaluated as targets for inducing a T-cell mediated protective response ${ }^{39,40}$ and consider their use in vaccine development (Fig. 2).

At present, about 14 vaccines are in clinical phase trials (Table 1). Several of these vaccines have shown 
Table 1. Approved clinical trials for SARS-CoV-2 vaccines

\begin{tabular}{|c|c|c|c|c|c|}
\hline Clinical trial & $\begin{array}{c}\text { Clinical } \\
\text { phase }\end{array}$ & Type of vaccine & Results & Developer & Registration \\
\hline $\begin{array}{l}\text { Ad5-nCov } \\
\text { vaccine }\end{array}$ & $\mathrm{I} / \mathrm{II}$ & $\begin{array}{l}\text { Recombinant vaccine } \\
\text { (adenovirus type } \\
5 \text { vector) }\end{array}$ & $\begin{array}{l}\text { Humoral and T-cell response were } \\
\text { induced rapidly in most participants. } \\
\text { A peak of IFN- } \gamma \text {, TNF- } \alpha \text {, and IL-2 } \\
\text { producing CD4+ and CD8+ T-cell } \\
\text { responses were observed on day } 14 \\
\text { after vaccination, as well as a peak } \\
\text { of antibodies specific for the S } \\
\text { protein and the RBD, which were } \\
\text { able to neutralize the SARS-CoV-2 } \\
\text { virus in vitro on day } 28\end{array}$ & $\begin{array}{l}\text { Beijing Institute of } \\
\text { Biotechnology and } \\
\text { CanSino Biologics Inc. }\end{array}$ & $\begin{array}{l}\text { NCT04313127 } \\
\text { NCT04341389 }\end{array}$ \\
\hline mRNA-1273 vaccine & $\mathrm{I} / \mathrm{II}$ & $\begin{array}{l}\text { Lipid nanoparticle } \\
\text { (LNP) dispersion } \\
\text { containing an mRNA } \\
\text { that encodes for the } \\
\text { prefusion spike protein } \\
\text { 2019-nCoV }\end{array}$ & $\begin{array}{l}\text { The vaccine was safe and } \\
\text { well-tolerated, inducing binding } \\
\text { antibody titers similar to or higher } \\
\text { than those from patients with the } \\
\text { disease. Furthermore, eight patients } \\
\text { produced neutralizing antibodies } \\
\text { (the rest of the samples have yet to } \\
\text { be analyzed). } \\
\text { In a mouse challenge model, it } \\
\text { provided complete protection } \\
\text { against viral replication in the lungs }\end{array}$ & Moderna Therapeutics & $\begin{array}{l}\text { NCT04283461 } \\
\text { NCT04405076 }\end{array}$ \\
\hline $\begin{array}{l}\text { AZD1222 vaccine } \\
\text { (ChAd0x1 nCoV-19) }\end{array}$ & II/III & $\begin{array}{l}\text { Attenuated chimpanzee } \\
\text { adenovirus capable of } \\
\text { producing protein S of } \\
\text { SARS-CoV-2 }\end{array}$ & Unpublished & $\begin{array}{l}\text { University of Oxford } \\
\text { AstraZeneca }\end{array}$ & $\begin{array}{l}\text { NCT04324606 } \\
\text { NCT04400838 }\end{array}$ \\
\hline IN0-4800 vaccine & I & $\begin{array}{l}\text { DNA vaccine which } \\
\text { encodes for the } S \\
\text { protein. }\end{array}$ & Unpublished & $\begin{array}{l}\text { Inovio } \\
\text { Pharmaceuticals }\end{array}$ & NCT04336410 \\
\hline $\begin{array}{l}\text { PR0-nCOV-1001 y } 002 \\
\text { vaccine }\end{array}$ & $\mathrm{I} / \mathrm{II}$ & Inactivated SARS-CoV-2 & Unpublished & $\begin{array}{l}\text { Sinovac Research \& } \\
\text { Development }\end{array}$ & $\begin{array}{l}\text { NCT04352608 } \\
\text { NCT04383574 }\end{array}$ \\
\hline 2019nCoV-101vaccine & I & $\begin{array}{l}\text { SARS-CoV-2 } \\
\text { Recombinant S Protein } \\
\text { Nanoparticle Vaccine }\end{array}$ & Unpublished & Novavax & NCT04368988 \\
\hline BNT-162 vaccine & $\mathrm{I} / \mathrm{II}$ & $\begin{array}{l}\text { Lipid nanoparticle } \\
\text { formulated mRNA } \\
\text { vaccine encoding } \\
\text { SARS-CoV-2 S protein }\end{array}$ & Unpublished & Pfizer/BioNTech SE & NCT04368728 \\
\hline $\begin{array}{l}\text { COVID-19 tablet } \\
\text { vaccine }\end{array}$ & $\mathrm{I} / \mathrm{II}$ & $\begin{array}{l}\text { Tablet with SARS- } \\
\text { CoV-2 inactivated from } \\
\text { the plasma of patients } \\
\text { with COVID-19 }\end{array}$ & Unpublished & Immuitor Inc. & NCT04380532 \\
\hline $\begin{array}{l}\text { GIMI-IRB-20002 } \\
\text { vaccine }\end{array}$ & 1 & $\begin{array}{l}\text { Lentiviral-based } \\
\text { artificial APC vaccine }\end{array}$ & Unpublished & $\begin{array}{l}\text { Shenzhen Geno- } \\
\text { Immune Medical } \\
\text { Institute }\end{array}$ & NCT04299724 \\
\hline LV-SMENP vaccine & $\mathrm{I} / \mathrm{II}$ & $\begin{array}{l}\text { Lentiviral-based } \\
\text { dendritic cell and T-cell } \\
\text { vaccine }\end{array}$ & Unpublished & $\begin{array}{l}\text { Shenzhen Geno- } \\
\text { Immune Medical } \\
\text { Institute }\end{array}$ & NCT04276896 \\
\hline SCB-2019 vaccine & I & $\begin{array}{l}\text { Recombinant SARS- } \\
\text { CoV-2 trimeric } \\
\text { S-protein subunit } \\
\text { vaccine }\end{array}$ & Unpublished & $\begin{array}{l}\text { Clover } \\
\text { Biopharmaceuticals } \\
\text { AUS Pty Ltd }\end{array}$ & NCT04405908 \\
\hline $\begin{array}{l}\text { bacTRL-Spike } 1 \\
\text { vaccine }\end{array}$ & I & $\begin{array}{l}\text { Bifidobacterium } \\
\text { longum CFUs, which } \\
\text { contain plasmids that } \\
\text { encode for the } \\
\text { SARS-CoV-2 S protein }\end{array}$ & Unpublished & Symvivo Corporation & NCT04334980 \\
\hline $\begin{array}{l}\text { Inactivated } \\
\text { SARS-CoV-2 vaccine }\end{array}$ & $\mathrm{I} / \mathrm{II}$ & $\begin{array}{l}\text { Inactivated SARS- } \\
\text { CoV-2 vaccine }\end{array}$ & Unpublished & $\begin{array}{l}\text { West China Second } \\
\text { University Hospital } \\
\text { Yunnan Center for } \\
\text { Disease Control and } \\
\text { Prevention }\end{array}$ & NCT04412538 \\
\hline
\end{tabular}


Table 1. Approved clinical trials for SARS-CoV-2 vaccines (Continued)

\begin{tabular}{|c|c|c|c|c|c|}
\hline Clinical trial & $\begin{array}{l}\text { Clinical } \\
\text { phase }\end{array}$ & Type of vaccine & Results & Developer & Registration \\
\hline $\begin{array}{l}\text { Autologous dendritic } \\
\text { cell vaccine }\end{array}$ & $\mathrm{I} / \mathrm{II}$ & $\begin{array}{l}\text { Autologous dendritic } \\
\text { cell vaccine loaded } \\
\text { with SARS-CoV-2 } \\
\text { antigens }\end{array}$ & Unpublished & Aivita Biomedical, Inc. & NCT04386252 \\
\hline Gam-COVID-Vac & $\mathrm{I} / \mathrm{II}$ & $\begin{array}{l}\text { Recombinant } \\
\text { adenovirus containing } \\
\text { the SARS-CoV-2 S } \\
\text { protein }\end{array}$ & Unpublished & $\begin{array}{l}\text { Gamaleya Research } \\
\text { Institute of } \\
\text { Epidemiology and } \\
\text { Microbiology, Health } \\
\text { Ministry of the } \\
\text { Russian Federation }\end{array}$ & $\begin{array}{l}\text { NCT04436471 } \\
\text { NCT04437875 }\end{array}$ \\
\hline
\end{tabular}

Information obtained from clinicaltrials.gov. APC, antigen-presenting cells; CFU, colony-forming units; COVID-19, coronavirus disease 2019; DNA, deoxyribonucleic acid; IFN- $\gamma$, interferon-gamma; IL-2, interleukin-2; mRNA, messenger ribonucleic acid; RBD, receptor-binding domain; S, spike protein; SARS-CoV-2, severe acute respiratory syndrome coronavirus 2; TNF- $\alpha$ : tumor necrosis factor-alpha.

promising results in animal models, protecting against the virus. Some propose the use of virus-specific T-cells and autologous dendritic cells as an interesting strategy to achieve protective immunity based on cellular immunity; however, evidence demonstrating the effectiveness of these approaches is still lacking.

One vaccine that has caught the attention is AZD1222 (ChAdOx1 nCoV-19), developed by the University of Oxford and AstraZeneca, which uses a platform that was first investigated in the MERS epidemic. This vaccine has shown encouraging results in murine and macaque models, protecting the development of pneumonia by inducing neutralizing antibodies and specific T-cell responses ${ }^{41}$. Moreover, human trials have begun, and the vaccine will soon move to Phase II/III (Table 1).

Furthermore, two research groups showed encouraging results in humans. Moderna Therapeutics, through its vaccine mRNA-1273, managed to induce neutralizing antibodies in all participants. They found at day 43 (2 weeks after the second dose) that the titers of these antibodies were higher than those observed in patients who have recovered from COVID-19. These results were obtained with the highest dose. Furthermore, in eight volunteers, it was possible to obtain neutralizing antibodies with titers comparable to those observed in a murine model, which were able to prevent viral replication in mice lungs. These results are still preliminary, and the analysis of a larger number of people has yet to be reported ${ }^{42}$. It has been announced that Phase III of this vaccine could start in July $2020^{43}$.

Meanwhile, researchers from the Beijing Institute of Biotechnology and CanSino Biologics developed the Ad5-nCov vaccine, which achieved, with its highest dose, to produce binding antibodies in all participants and neutralizing antibodies in $75 \%$ of them after 28 days of vaccination. Furthermore, it induced responses in IFN- $\gamma$, TNF- $\alpha$, and IL-2 producing CD4+ and CD8+
T-cells within 14 days of the vaccine application ${ }^{44}$; however, this vaccine has a disadvantage, since antibodies against the Ad5 vector exist in large part of the population, which could diminish its effectiveness.

A large number of clinical trials are being conducted, and many will follow in the future. However, it is estimated that only about $6 \%$ will be completed ${ }^{45}$. Given the demand that exists, a single vaccine cannot supply the global needs, as a large production and distribution will be required shortly. Therefore, it is likely that each country or region will develop its vaccine. Eventually, after administering each available vaccine, we will obtain results that will show which vaccine is the most efficient.

The full development of an effective vaccine against SARS-CoV-2 will still take several months; for this reason, alternatives have been sought to help in conferring protection with existing vaccines. Controlled trials have recently begun in several countries to assess whether BCG (Bacillus Calmette Guerin) vaccine can reduce the incidence and severity of COVID-19 in health care workers as this vaccine appears to have non-specific effects on the innate immune system, shown by the reduction in the severity of some viral infections. For example, in one experimental infection model, BCG vaccination reduced viremia caused by live attenuated yellow fever virus by $71 \%{ }^{46}$, while in other studies in South Africa, BCG vaccine reduced respiratory tract infections by $73 \%$ in adolescents ${ }^{47}$.

Recently, the mechanisms of the non-specific immune effects produced by BCG were described. It has been observed that vaccination with this bacillus induces transcriptional, metabolic, and epigenetic reprogramming that improves the innate immune response to subsequent infections, a process that has been called "immune training"18. This response is associated with epigenetic changes, such as methylation and acetylation of histones ${ }^{49}$ at promoter sites of genes 
encoding pro-inflammatory cytokines in monocytes, and correlates with improved antiviral responses compared to monocytes from adults who did not receive the vaccine ${ }^{46}$

Given the evidence of cross-immunity caused by BCG, its use for protection against COVID-19 could be considered. Some epidemiological studies indicate that countries without a BCG vaccination policy, such as Italy and the United States, have been more affected by the pandemic compared to countries with a standard BCG vaccination policy (Japan and South Korea), where fewer cases of COVID-19 were observed. However, these effects could also be related to health measures and the characteristics of the population of each country. It has been observed that protection lasts about 15 years ${ }^{50}$, suggesting that the prophylactic effect in the countries whose inhabitants received the vaccine would only occur in the young population. It is also possible that the BCG vaccine may be harmful in some instances due to the increased innate immune response because an exacerbated cytokine response has been associated with complications in patients with COVID-1949. With this evidence, it is clear that there is a lack of controlled clinical studies to verify whether the $B C G$ vaccine could confer protection against COVID-19 and whether this would work as an alternative to reduce the number of severe cases and the number of positive cases. Furthermore, it is necessary to evaluate its impact as a tool in response to SARS-CoV-2 and for future pandemics, while waiting for the development of a specific vaccine that demonstrates safety and efficiency.

In recent days, the WHO has pointed out that the pandemic is not over. Although in some countries the situation is improving, the global picture is worsening. Moreover, a second outbreak of the virus is expected in the coming months. This review shows that there is still much research to be done to have a competent vaccine in the market. Data obtained are still preliminary; however, the first human studies suggest that it is possible to generate antibodies and cellular immunity against SARS-CoV-2. These observations are consistent with animal models that have been tested against the virus, where the immune response can inhibit viral replication and lung damage. We need to have definitive results in human volunteers, study the duration of the immunity developed, and evaluate whether the vulnerable population (such as the elderly) develops the same protective response. Furthermore, it is necessary to assess the cost-benefit ratio of the protection versus the adverse effects presented. It is also important not to be limited to S-protein-based vaccines but include $\mathrm{M}$ and NP proteins to induce balanced humoral and T-cell responses. Data presented in this review provide a broader perspective on the development of efficient vaccines for COVID-19, which will significantly benefit society in helping the global population to move out of confinement, to restore social and economic activities, and, above all, to save countless lives.

\section{Addendum}

\section{SARS-CoV-2: previous coronaviruses, immune response, and development of vaccines. Update of July 18, 2020}

In recent days, many laboratories have published their first Phase studies results. One vaccine that has made recent progress is the Ad5-nCoV developed by CanSino Biologics, which has not published its Phase II results but has managed to be approved by the Chinese government for its use in the military. This use would position it as the first vaccine to be approved ${ }^{51}$.

Moderna Therapeutics has published its Phase I results of the vaccine mRNA-1273, indicating that all the participants elicited robust neutralizing antibodies titers after the second dose, where their levels were very similar to convalescent patients. Furthermore, the vaccine produced $\mathrm{CD} 4+\mathrm{T}$-cell responses specific to the $S$ protein on the group of $100 \mu \mathrm{g}$ at day 43 . These cells produced Th1 cytokines such as TNF $\alpha$, IL-2, and IFN $\gamma$; also, CD8+ T-cell responses were deficient. In groups of 100 and $250 \mu \mathrm{g}$, all patients presented moderate adverse effects after the second dose ${ }^{52}$.

Oxford University has announced the start of Phase II/III. The Brazilian Health Regulatory Agency (ANVISA) approved the inclusion of Brazil in the clinical trials ${ }^{53}$. Recent reports from The Telegraph affirm that the vaccine is capable of inducing a humoral and cellular immune response. Furthermore, the Phase I results are expected to be published on July 20 in The Lancet ${ }^{54}$.

Pfizer/BioNTech published preliminary results of its BNT162b1 vaccine, whose $10 \mu \mathrm{g}$ and $30 \mu \mathrm{g}$ doses induced neutralizing antibody levels 1.8 and 2.8 times, respectively, higher than the observed in COVID-19 convalescent patients. Local reactions and systemic events were generally mild to moderate and transient. No serious adverse events were reported ${ }^{55}$.

INOVIO has announced that $94 \%$ of Phase I trial participants demonstrated overall immune responses at week 6 after two doses of the INO-4800 vaccine. Through week 8 , the INO-4800 regime was deemed 
safe and well-tolerated with no serious adverse events. Meanwhile, in a preclinical animal study, INO-4800 provided full protection against SARS-CoV-2 replication in the lungs in mice challenged with the virus. INOVIO to begin Phase II/III efficacy study this summer ${ }^{56}$.

The vaccine PRO-nCOV-1 developed by Sinovac, and an inactivated-virus vaccine developed by Sinopharm launched their Phase III clinical trials in July ${ }^{57}$. The Russian vaccine developed by Gamaleya Research Institute, a combination of two adenovirus Ad5 and Ad26 and RNA vaccine developed by Imperial College London, started Phase I trial in June ${ }^{57-59}$.

\section{Ethical disclosures}

Protection of human and animal subjects. The authors declare that no experiments were performed on humans or animals for this study.

Confidentiality of data. The authors declare that they have followed the protocols of their work center on the publication of patient data.

Right to privacy and informed consent. The authors declare that no patient data appear in this article.

\section{Conflicts of interest}

The authors declare that they have no conflicts of interest.

\section{Funding}

None.

\section{Acknowledgments}

We are grateful to Dr. Ricardo Andrés León Letelier.

\section{References}

1. Gobierno de México. Mexico: covid-19 México Datos. Available from: https://www.coronavirus.gob.mx/datos.

2. Organización Mundial de la Salud. Geneva: alocución de Apertura del Director General de la OMS en la Rueda de Prensa Sobre la COVID-19 Celebrada el 11 de Marzo de 2020. Available from: https://www.who.int/ es/dg/speeches/detail/who-director-general-s-opening-remarks-at-themedia-briefing-on-covid-19---11-march-2020.

3. The Johns Hopkins University of Medicine. Baltimore: COVID-19 Dashboard by the Center for Systems Science and Engineering (CSSE) at Johns Hopkins University (JHU). Available from: https://www.coronavirus. jhu.edu/map.html.

4. Chen G, Wu D, Guo W, Cao Y, Huang D, Wang H, et al. Clinical and immunological features of severe and moderate coronavirus disease 2019. J Clin Invest. 2020;130:2620-9.

5. Agrati C, Sacchi A, Bordoni V, Cimini E, Notari S, Grassi G, et al. Expansion of myeloid-derived suppressor cells in patients with severe coronavirus disease (COVID-19). Cell Death Differ. 2020;2020:1-12.

6. Huang C, Wang Y, Li X, Ren L, Zhao J, Hu Y, et al. Clinical features of patients infected with 2019 novel coronavirus in Wuhan, China. Lancet. 2020;395:497-506.
7. Tang D, Comish P, Kang R. The hallmarks of COVID-19 disease. PLoS Pathog. 2020;16:1-24.

8. Jia HP, Look DC, Shi L, Hickey M, Pewe L, Netland J, et al. ACE2 receptor expression and severe acute respiratory syndrome coronavirus infection depend on differentiation of human airway epithelia. J Virol. 2005;79:14614-21.

9. Xu H, Zhong L, Deng J, Peng J, Dan H, Zeng X, et al. High expression of ACE2 receptor of 2019-nCoV on the epithelial cells of oral mucosa. Int J Oral Sci. 2020;12:1-5.

10. Hamming I, Timens W, Bulthuis ML, Lely AT, Navis GJ, van Goor H. Tissue distribution of ACE2 protein, the functional receptor for SARS coronavirus. A first step in understanding SARS pathogenesis. J Pathol. 2004;203:631-7.

11. Xiao X, Chakraborti S, Dimitrov AS, Gramatikoff K, Dimitrov DS. The SARS-CoV S glycoprotein: expression and functional characterization. Biochem Biophys Res Commun. 2003;312:1159-64.

12. Fehr AR, Perlman S. Coronaviruses: an overview of their replication and pathogenesis. Methods Mol Biol. 2015;1282:1-23.

13. Wu F, Wang A, Liu M, Wang Q, Chen J, Xia S, et al. Neutralizing antibody responses to SARS-CoV-2 in a COVID-19 recovered patient cohort and their implications. medRxiv. 2020; doi: 10.1101/2020.03.30.20047365. Unrefereed preprint.

14. Korea Centers for Disease Control and Prevention (KCDC). Findings from Investigation and Analysis of Re-positive Cases. Available from: https:// www.is.cdc.go.kr/upload comm/syview/doc.html?fn=159118745823700. pdf\&rs=/upload_comm/docu/0030.

15. Zhou $P$, Yang XL, Wang XG, Hu B, Zhang L, Zhang W, et al. A pneumonia outbreak associated with a new coronavirus of probable bat origin. Nature. 2020;579:270-3.

16. Graham RL, Donaldson EF, Baric RS. A decade after SARS: strategies for controlling emerging coronaviruses. Nat Rev Microbiol. 2013;11: 836-48.

17. Song Z, Xu Y, Bao L, Zhang L, Yu P, Qu Y, et al. From SARS to MERS, thrusting coronaviruses into the spotlight. Viruses. 2019;11:1-28.

18. Chu H, Zhou J, Wong BH, Li C, Chan JF, Cheng ZS, et al. Middle East respiratory syndrome coronavirus efficiently infects human primary $T$ lymphocytes and activates the extrinsic and intrinsic apoptosis pathways. J Infect Dis. 2016;213:904-14.

19. Chu H, Zhou J, Wong BH, Li C, Cheng ZS, Lin X, et al. Productive replication of Middle East respiratory syndrome coronavirus in monocyte-derived dendritic cells modulates innate immune response. Virology. 2014; 454-455:197-205

20. Lau SK, Lau CC, Chan KH, Li CP, Chen H, Jin DY, et al. Delayed induction of pro-inflammatory cytokines and suppression of innate antiviral response by the novel Middle East respiratory syndrome coronavirus: implications for pathogenesis and treatment. J Gen Virol. 2013;94:2679-90.

21. Zhou J, Chu H, Li C, Wong BH, Cheng ZS, Poon VK, et al. Active replication of Middle East respiratory syndrome coronavirus and aberrant induction of inflammatory cytokines and chemokines in human macrophages: implications for pathogenesis. J Infect Dis. 2014;209:1331-42.

22. Memish ZA, Perlman S, Van Kerkhove MD, Zumla A. Middle East respiratory syndrome. Lancet. 2020;395:1063-77.

23. Corman VM, Albarrak AM, Omrani AS, Albarrak MM, Farah ME, Almasri $\mathrm{M}$, et al. Viral shedding and antibody response in 37 patients with Middle East respiratory syndrome coronavirus infection. Clin Infect Dis. 2016;62:477-83

24. Shin HS, Kim Y, Kim G, Lee JY, Jeong I, Joh JS, et al. Immune responses to Middle East respiratory syndrome coronavirus during the acute and convalescent phases of human infection. Clin Infect Dis. 2019; 68:984-92.

25. Zhao J, Alshukairi AN, Baharoon SA, Ahmed WA, Bokhari AA, Nehdi AM, et al. Recovery from the Middle East respiratory syndrome is associated with antibody and T-cell responses. Sci Immunol. 2017;2:1-10.

26. Alshukairi AN, Khalid I, Ahmed WA, Dada AM, Bayumi DT, Malic LS, et al. Antibody response and disease severity in healthcare worker MERS survivors. Emerg Infect Dis. 2016;22:1113-5.

27. Mo H, Xu J, Ren X, Zeng G, Tan Y, Chen R, et al. Evaluation by indirect immunofluorescent assay and enzyme-linked immunosorbent assay of the dynamic changes of serum antibody responses against severe acute respiratory syndrome coronavirus. Chin Med J Engl. 2005;118:446-50.

28. Xu X, Gao X. Immunological responses against SARS-coronavirus infection in humans. Cell Mol Immunol. 2004;1:119-22.

29. Zhong $X$, Yang H, Guo ZF, Sin WY, Chen W, Xu J, et al. B-cell responses in patients who have recovered from severe acute respiratory syndrome target a dominant site in the S2 domain of the surface spike glycoprotein. J Virol. 2005;79:3401-8.

30. Amanat F, Krammer F. SARS-CoV-2 vaccines: status report. Immunity. 2020;52:583-9.

31. Tseng CT, Sbrana E, Iwata-Yoshikawa N, Newman PC, Garron T, Atmar RL, et al. Immunization with SARS coronavirus vaccines leads to pulmonary immunopathology on challenge with the SARS virus. PLoS One. 2012;7:1-13. 
32. Al-Amri SS, Abbas AT, Siddiq LA, Alghamdi A, Sanki MA, Al-Muhanna MK et al. Immunogenicity of candidate MERS-CoV DNA vaccines based on the spike protein. Sci Rep. 2017;7:1-8.

33. Muthumani K, Falzarano D, Reuschel EL, Tingey C, Flingai $S$, Villarreal DO, et al. A synthetic consensus anti-spike protein DNA vaccine induces protective immunity against Middle East respiratory syndrome coronavirus in nonhuman primates. Sci Transl Med. 2015;7:1-14.

34. See RH, Zakhartchouk AN, Petric M, Lawrence DJ, Mok CP, Hogan RJ, et al. Comparative evaluation of two severe acute respiratory syndrome (SARS) vaccine candidates in mice challenged with SARS coronavirus. J Gen Virol. 2006:87:641-50.

35. Schindewolf $C$, Menachery VD. Middle East respiratory syndrome vaccine candidates: cautious optimism. Viruses. 2019;11:1-17.

36. Folegatti PM, Bittaye M, Flaxman A, Lopez FR, Bellamy D, Kupke A et al. Safety and immunogenicity of a candidate Middle East respiratory syndrome coronavirus viral-vectored vaccine: a dose-escalation, open-label, non-randomised, uncontrolled, Phase 1 trial. Lancet Infect Dis. 2020;20:816-26

37. Long QX, Tang XJ, Shi QL, Li Q, Deng HJ, Yuan J, et al. Clinical and immunological assessment of asymptomatic SARS-CoV-2 infections. Nat Med. 2020;26:1200-4.

38. Liao M, Liu Y, Yuan J, Wen Y, Xu G, Zhao J, et al. Single-cell landscape of bronchoalveolar immune cells in patients with COVID-19. Nat Med. 2020;26:842-4.

39. Grifoni A, Weiskopf D, Ramirez SI, Mateus J, Dan JM, Rydyznski-Moderbacher $\mathrm{C}$, et al. Targets of T cell responses to SARS-CoV-2 coronavirus in humans with COVID-19 disease and unexposed individuals. Cell. 2020;181:1489-501.

40. Peng Y, Mentzer AJ, Liu G, Yao X, Yin Z, Dong D, et al. Broad and strong memory CD4+ and CD8+ T cells induced by SARS-CoV-2 in UK convalescent COVID-19 patients. Nat Immunol; 2020. Online ahead of print https://doi.org/10.1038/s41590-020-0782-6.

41. van Doremalen N, Lambe T, Spencer A, Belij-Rammerstorfer S, Purushotham JN, Port JR, et al. ChAdOx1 nCoV-19 vaccination prevents SARS-CoV-2 pneumonia in rhesus macaques. bioRxiv. 2020; doi: 10.1101/2020.05.13.093195. Unrefereed preprint.

42. Moderna. Massachusetts: Moderna Announces Positive Interim Phase 1 Data for its mRNA Vaccine (mRNA-1273) Against Novel Coronavirus. Available from: https://www.investors.modernatx.com/node/8986/pdf

43. Moderna. Massachusetts: Moderna Announces the First Participants in Each Age Cohort Dosed in Phase 2 Study of mRNA Vaccine (mRNA1273) Against Novel Coronavirus. Available from: https://www.investors. modernatx.com/node/9116/pdf.

44. Zhu FC, Li YH, Guan XH, Hou LH, Wang WJ, Li JX, et al. Safety, tolerability, and immunogenicity of a recombinant adenovirus Type- 5 vectored COVID-19 vaccine: a dose-escalation, open-label, non-randomised, first-in-human trial. Lancet. 2020;395:1845-54
45. Mullard A. World report COVID-19 vaccine development pipeline gears up. Lancet. 2020;395:1751-2.

46. Arts RJ, Moorlag SJ, Novakovic B, Li Y, Wang SY, Oosting M, et al. BCG vaccination protects against experimental viral infection in humans through the induction of cytokines associated with trained immunity. Cell Host Microbe. 2018;23:89-100

47. Nemes E, Geldenhuys H, Rozot V, Rutkowski KT, Ratangee F, Bilek N, et al. Prevention of $M$. tuberculosis infection with $\mathrm{H} 4: \mathrm{IC} 31$ vaccine or BCG revaccination. N Engl J Med. 2018;379:138-49.

48. Goodridge HS, Ahmed SS, Curtis N, Kollmann TR, Levy O, Netea MG, et al. Harnessing the beneficial heterologous effects of vaccination. Nat Rev Immunol. 2016;16:392-400.

49. O'Neill LA, Netea MG. BCG-induced trained immunity: can it offer protection against COVID-19? Nat Rev Immunol. 2020;20:335-7.

50. Kantor IN. BCG versus COVID-19?. Medicina (Buenos Aires). 2020;80:292-4.

51. Reuters. CanSino's COVID-19 Vaccine Candidate Approved for Military Use in China. Available from: https://www.reuters.com/article/us-health-coronavirus-china-vaccine/cansinos-covid-19-vaccine-candidate-approved-for-military-use-in-china-idUSKBN2400DZ.

52. Jackson LA, Anderson EJ, Rouphael NG, Roberts PC, Makhene M, Coler RN, et al. An mRNA vaccine against SARS-CoV-2-preliminary report. N Engl J Med. 2020;2020:2022483.

53. Oxford University, London. Trial of the Oxford COVID-19 Vaccine Starts in Brazil. Available from: https://www.ox.ac.uk/news/2020-06-28-trialoxford-covid-19-vaccine-starts-brazil.

54. The Telegraph. Coronavirus Vaccine Hopes Rise After Strong Trial Results. Available from: https://www.telegraph.co.uk/news/2020/07/15/coronavirus-vaccine-breakthrough-oxford-scientists-discover.

55. Pfizer. Pfizer and Biontech Announce Early Positive Data from an Ongoing Phase 1/2 Study of mRNA-based Vaccine Candidate Against SARS-Cov-2. Available from: https://www.pfizer.com/news/press-release/ press-release-detail/pfizer-and-biontech-announce-early-positive-data-ongoing-0.

56. INOVIO. INOVIO Announces Positive Interim Phase 1 Data for INO-4800 Vaccine for COVID-19. Available from: http://www.ir.inovio.com/news-releases/news-releases-details/2020/INOVIO-Announces-Positive-Interim-Phase-1-Data-For-INO-4800-Vaccine-for-COVID-19/default.aspx.

57. The New York Times. Coronavirus Vaccine Tracker. Available from: https://www.nytimes.com/interactive/2020/science/coronavirus-vaccine-tracker.html\#russiahealth.

58. Reuters. Russia to Mass-produce Experimental COVID-19 Vaccine: Wealth Fund Head. Available from: https://www.reuters.com/article/ us-health-coronavirus-russia-vaccine/russia-to-mass-produce-experimental-covid-19-vaccine-wealth-fund-head-idUSKCN24H1AD.

59. Imperial College of London. Imperial's COVID-19 Vaccine Moves to the Next Phase. Available from: http://www.imperial.ac.uk/news/199993/imperials-covid-19-vaccine-moves-next-phase. 